\title{
Analisis Perubahan Luasan Hutan Mangrove Di Kecamatan Brebes Dan Wanasari, Kabupaten Brebes Menggunakan Citra Satelit Landsat Tahun 2008, 2013 Dan 2018
}

\author{
Amin Yunita Nur Annisa*, Rudhi Pribadi, Ibnu Pratikto \\ Departemen IImu Kelautan, Fakultas Perikanan dan IImu Kelautan, Universitas Diponegoro \\ JI. Prof.H.Soedarto S.H, Tembalang,Semarang, Jawa Tengah 50275 Indonesia \\ *Corresponding author, e-mail : aminisa327@gmail.com
}

\begin{abstract}
ABSTRAK : Mangrove merupakan ekosistem daerah peralihan yang memiliki beberapa fungsi diantaranya ekologis, fisik maupun ekonomi. Kerusakan mangrove sering terjadi di beberapa daerah sehingga kelestarian mangrove sangat perlu dijaga. Salah satu upaya untuk mengurangi kerusakan tersebut dengan kegiatan rehabilitasi. Kegiatan rehabilitasi ini bertujuan untuk memulihkan kondisi mangrove seperti keadaan semula. Keberhasilan dari kegiatan rehabilitasi ini dapat dipantau dengan sistem penginderaan jauh menggunakan citra Satelit Landsat. Penelitian ini dilakukan pada bulan Juni- Juli 2018. Metode penelitian ini menggunakan metode deskriptif bersifat eksploratif. Materi dalam penelitian ini adalah data citra satelit Landsat 5 untuk tahun 2008 dan Landsat 8 untuk tahun 2018. Berdasarkan hasil penelitian didapatkan nilai perubahan luasan hutan mangrove di Desa Kaliwlingi, Kecamatan Brebes dan Desa Sawojajar, Kecamatan Wanasari tahun 2008, 2013 dan 2018. Luas mangrove di Desa Kaliwlingi Kecamatan Brebes pada tahun 2008-2013 bertambah sebesar 101,25 ha yaitu 48,42 ha pada tahun 2008 dan 149,67 ha pada tahun 2013. Pada tahun 2013-2018 juga bertambah 184,23 ha yakni 333,9 ha pada tahun 2018. Pada Desa Sawojajar Kecamatan Wanasari, luas mangrove juga bertambah sebesar 0,09 ha yakni 24,39 ha pada tahun 2008 bertambah menjadi 24,48 ha pada tahun 2013. Tahun 2013-2018 juga bertambah sebesar 12,24 ha sehingga menjadi 36,72 ha di tahun 2018 . Luas mangrove di Desa Kaliwlingi dan Sawojajar bertambah dalam kurun waktu sepuluh tahun.
\end{abstract}

Kata Kunci: Mangrove; Rehabilitasi; Landsat

\section{Analysis of Changes in Mangrove Forest Areas in Brebes and Wanasari Districts, Brebes Regency Using Landsat Satellite Imagery in 2008, 2013 and 2018}

ABSTRACT : Mangroves are transitional ecosystems that have several functions including ecological, physical and economic. Mangrove damage often occurs in several areas so that the preservation of mangroves is very important. One effort to reduce this damage is through rehabilitation activities. This rehabilitation activity aims to restore the condition of mangroves as they were before. The success of these rehabilitation activities can be monitored by remote sensing systems using Landsat Satellite imagery. This research was conducted in June-July 2018. This research method uses descriptive methods that are alternative. The material in this study is Landsat 5 satellite image data for 2008 and Landsat 8 for 2018. Based on the results of the study, the value of changes in a mangrove forests in Kaliwlingi Village, Brebes and Sawojajar Villages, Wanasari District in 2008, 2013 and 2018. The area of mangroves in Kaliwlingi Village, Brebes Subdistrict in 2008-2013 it increased by 101.25 ha, which was 48.42 ha in 2008 and 149.67 ha in 2013. In 2013-2018 it also increased by 184.23 ha, namely 333.9 ha in 2018. In Sawojajar Village, Wanasari Subdistrict, the area of mangroves also increased by 0.09 ha, which was 24.39 ha in 2008 which increased to 24.48 ha in 2013. 2013-2018 also increased by 12.24 ha to 36.72 ha in 2018. The area of mangrove in Kaliwlingi and Sawojajar villages has increased in ten years.

Keywords: Mangrove; Rehabilitation; Landsat 


\section{PENDAHULUAN}

Mangrove merupakan ekosistem daerah peralihan antara darat dan laut yang banyak dipengaruhi oleh gelombang, topografi pantai dan pasang surut air laut. Proses dekomposisi serasah bakau yang terjadi mampu menunjang kehidupan makhluk hidup di dalamnya. Mangrove dapat tumbuh subur di daerah muara sungai dan estuari dan kesuburan mangrove sendiri dipengaruhi oleh adanya pasang surut yang mentrasnportasi nutrient.

Ekosistem mangrove memiliki fungsi fisik, biologi dan ekonomi. Fungsi secara fisik yaitu menjaga garis pantai agar tetap stabil atau mencegah kerusakan pantai dari bahaya erosi pantai dan mempercepat terjadinya perluasan pantai dan pulau. Fungsi bioologi sebagai nursery ground, feeding ground dan spawning ground. Fungsi ekonomi sebagai tempat pengambilan kayu dan kulit kayu, tempat budidaya tambak ikan dan udang dan tempat wisata (Purnamawati et al., 2007).

Menurut Poedjiraharjoe et al., (2011), Tiga faktor utama penyebab kerusakan mangrove yaitu pencemaran, konversi hutan mangrove yang kurang memperhatikan faktor lingkungan dan penebangan yang berlebihan. Sehingga hutan mangrove tidak dapat berfungsi sebagai daerah nursery ground, feeding ground, spawning ground menjadi terganggu. Oleh karena itu diperlukan kegiatan rehabilitasi hutan mangrove untuk memulihkan dan mengembalikan fungsi perlindungan, pelestarian dan fungsi produksinya. Upaya rehabilitasi dapat dilakukan dengan cara penghijauan maupun sosialisasi kepada masyarakat sekitar mengenai kesadaran dan pentingnya ekosistem mangrove.

Rehabilitasi dilakukan dengan tujuan mengembalikan fungsi ekosistem hutan mangrove seperti semula. Dalam menangani upaya rehabilitasi, salah satunya dengan menggunakan sistem penginderaan jauh. Sistem penginderaan jauh secara multi temporal dilakukan untuk memperoleh informasi berkala dari setiap data citra dengan tahun pengamatan yang berbeda sehingga hasil yang diperoleh dapat dibandingkan dari tahun ke tahun. Data penginderaan jauh mampu menyediakan informasi obyektif dan akurat, pemantauan dan evaluasi (Dahuri, 1999).

\section{MATERI DAN METODE}

Materi yang digunakan dalam penelitian adalah vegetasi mangrove yang berada di Desa Kaliwlingi, Kecamatan Brebes dan Desa Sawojajar, Kecamatan Wanasari yang memanfaatkan citra satelit Landsat 5 waktu perekaman 3 Juli 2008 dan Landsat 8 dengan waktu perekaman 2 Agustus 2013 dan 16 Agustus 2018. Data citra ini dapat diakses di (https://earthexplorer. usgs.gov/). Penelitian ini berdasarkan analisis citra satelit Landsat 5 tahun 2008 dan citra satelit Landsat tahun 2013 dan 2018 dengan menggunakan metode Normalized Difference Vegetation Index (NDVI).

Metode yang digunakan dalam penelitian ini adalah metode deskriptif bersifat eksploratif bertujuan untuk menggambarkan keadaan sebagaimana adanya dan mengungkapkan fakta- fakta yang ada. Tujuan dari penelitian deskriptif adalah untuk membuat deskripsi, gambaran atau lukisan secara sistematis, faktual dan akurat mengenai fakta- fakta, sifat- sifat serta hubungan antarfenomena yang diselidiki. Fenomena yang terjadi pada penelitian ini adalah perubahan luasan mangrove di wilayah Desa Kaliwlingi, Kecamatan Brebes dan Desa Sawojajar, Kecamatan Wanasari menggunakan data citra satelit tahun 2008, 2013 dan 2018.

Pengolahan citra satelit menggunakan software Er Mapper 7.0 dan ArcGIS 10.3. Penggabungan citra adalah menggabungkan tiap piksel dari band- band yang digunakan sehingga menjadi gambar baru yang akan diolah pada tahap selanjutnya. Koreksi radiometri merupakan pemrosesan gambar digital untuk meningkatkan nilai kecerahan. Tujuan koreksi ini adalah mengurangi pengaruh kesalahan nilai kecerahan gambar yang dapat membatasi kemampuan seseorang untuk menafsirkan atau memproses secara kuantitatif dan menganalisis citra (Aryastana et al., 2017). Koreksi geometri dilakukan untuk memperbaiki kesalahan antara koordinat lokasi data citra dengan koordinat lokasi sebenarnya. Cropping citra adalah langkah untuk memotong citra sesuai dengan batas adminsitrasi dari daerah penelitian.data satu scene mencakup wilayah yang cukup luas, misalnya path/row 121/65 yang merupakan wilayah Jawa Tengah dan Jawa Barat. Penajaman citra bertujuan untuk memperjelas kenampakan objek pada citra sehingga semakin informatif. Salah satu teknik penajaman citra yang diterapkan untuk 
kerapatan dan distribusi vegetasi adalah False Color Composite (FCC). Citra komposit warna False Color Composite dibuat dengan mengkombinasikan tiga kanal yaitu kanal dengan urutan filter merah (red/R), filter hijau (green/G) dan filter biru (blue/B) (RGB).

Klasifikasi multispektral dilakukan untuk mendapatkan peta tematik yakni peta yang terdiri dari bagian- bagian yang telah dikelompokkan ke dalam kelas- kelas tertentu yang mempresentasikan suatu kelompok objek yang sama. Pada tahap klasifikasi multispektral ini menggunakan metode NDVI (Normalized Difference Vegetation Index). Dalam membedakan objek vegetasi mangrove dengan vegetasi jenis lain (non- mangrove) digunakan anlisis NDVI. Dengan transformasi NDVI tersebut, vegetasi mangrove akan terlihat lebih kontras dengan proporsi tingkat kecerahan yang lebih tinggi. Hal ini dikarenakan dalam pemanfaatan NDVI menggunakan gelombang NIR dan gelombang $\mathrm{R}$ dimana gelombang NIR sangat peka akan klorofil vegetasi. Transformasi NDVI merupakan salah satu produk standar NOAA (National Oceanic and Atmospheric Administration), satelit cuaca yang berorbit polar namun memberi perhatian khusus pada fenomena global vegetasi (Tucker, 1986).

Tabel 1. Nilai NDVI dengan kerapatan vegetasi

\begin{tabular}{ll}
\hline Kerapatan Vegetasi & Nilai NDVI $(\mu \mathrm{m})$ \\
\hline Sangat baik & $0.72-0.92$ \\
Baik & $0.42-0.72$ \\
Normal & $0.22-0.42$ \\
Buruk & $0.12-0.22$ \\
Sangat buruk & $-0.1-0.22$ \\
\hline
\end{tabular}

Sumber: Putra et al., 2017

Setiap kerapatan vegetasi ditemukan dari individu- individu tumbuhan bervariasi yang menutupi permukaan tanah. Kerapat tersebut dapat diformulasikan dengan transformasi NDVI. Transformasi NDVI dapat dirumuskan sebagai berikut:

$$
N D V I=\frac{(N I R-R E D)}{(N I R+R E D)}
$$

Keterangan: NDVI : Normalized Difference Vegetatiion Index; NIR : Band infra merah dekat (Near Infra-Red); RED : Band merah

Uji validasi ini dilakukan untuk mengecek kebenaran lokasi penelitian dan validasi data kerapatan hasil analisis dari citra satelit dengan data kerapatan yang didapat di lapangan. Data validasi di lapangan akan dicocokkan dengan data kerapatan hasil analisis citra. Posisi geografis lokasi pengamatan ditentukandengan mengukur koordinat lokasi pengamatan lapangan menggunakan GPS. Uji validasi data dilakukan setelah proses pengklasifikasian tutupan lahan pada citra dengan menggunakan metode interpretasi citra satelit secara visual kemudian dilakukan pengecekan langsung ke lapangan untuk memastikan kebenaran data yang diperoleh dari proses pengklasifikasian tersebut. Uji validasi data hanya diperuntukkan untuk mangrove dan non mangrove.

\section{HASIL DAN PEMBAHASAN}

Lokasi penelitian terletak di Desa Kaliwlingi, Kecamatan Brebes dan Sawojajar, Kecamatan Wanasari. Lokasi tersebut telah mengalami abrasi yang menyebabkan luas daratan berkurang dan tambak menjadi terendam, namun masyarakat bersama kelompok sadar wisata telah melakukan rehabilitasi (penanaman) mangrove secara berkala dengan tujuan dapat mengurangi abrasi. Rehabilitasi telah dilakukan tiap tahun yang bekerjasama dengan pihak pemerintah kota setempat.

Secara ekonomi, masyarakat juga memanfaatkan hutan mangrove bagi perekonomian mereka. Kegiatan yang paling menonjol yaitu adanya wisata hutan mangrove di desa Kaliwlingi yang disebut "Dewi Mangrovesari". Sedangkan di desa Sawojajar disebut "Pulau Cemara". Akan tetapi berdasarkan hasil survei lapangan, kondisi kedua wisata tersebut sangat berbeda. Pada desa Kaliwlingi, mangrove yang ditanam di daerah wisata dapat dikatakan cukup banyak. Hal itu 
berbanding terbalik dengan keadaan di Pulau Cemara. Di Pulau Cemara mangrove yang terlihat sangat sedikit dikarenakan pulau cemara adalah pantai buatan. Namun di Pulau Cemara sedang dilakukan penanaman berkala pada tahun 2018. Hal ini dikarenakan terdapatnya bibit mangrove yang berada di lokasi dan beberapa sudah ada yang ditanam. Luas hutan mengrove di Kaliwlingi tahun 2018 berkisar 333.9 ha. Sedangkan kondisi mangrove di Sawojajar, luasnya berkisar 36.72 ha. Namun pada duadesa tersebut mangrove yang dominan adalah Rizhophora mucronata dan Avicennia marina.

Perubahan luas mangrove di Desa Kaliwlingi dalam kurun waktu lima tahun mengalami penambahan. Tahun 2008 luas mangrove sebesar 48,42 ha, bertambah 101,25 ha sehingga menjadi 149,67 ha tahun 2013. Tahun 2018 masih bertambah 184,23 ha, luasannya menjadi 333,9 ha. Hal ini dikarenakan keberhasilan rehabilitasi yang telah dilakukan sejak 2005 dimana persentase keberhasilan rehabilitasi berkisar 75\%-90\% di tahun 2008 dan 2013. Selain itu dapat dilihat di Gambar 1 perubahan mangrove berdasarkan tingkat kerapatan. Dalam kurun waktu lima tahun, kategori jarang semakin menurun sedangkan kategori sedang dan rapat semakin bertambah. Hal ini dikarenakan dari waktu ke waktu bibit mangrove yang berhasil tumbuh akan semakin besar. Sehingga bibit mangrove yang awalnya ditanam dengan kerapatan jarang, lama kelamaan akan berubah menjadi kerapatan sedang dan rapat. Pada Gambar 6 juga dapat dilihat perubahan luas hutan mangrove berdasarkan analisa citra satelit dengan metode overlay berdasarkan nilai NDVI. Hutan mangrove di kawasan pesisir Desa Kaliwlingi tersebar di muara sungai, pesisir pantai berlumpur dan sebagian tumbuh di areal tambak. Penambahan mangrove di daerah muara dapat disebabkan karena propagul yang jatuh dan terbawa arus hingga ke muara. $\mathrm{Hal}$ ini dikarenakan di muara paling banyak terdapat jenis mangrove Avicennia. Menurut informasi yang diperoleh dari wawancara pribadi kepada salah satu pengelola ekowisata yaitu Bangkit, Avicennia di daerah muara tumbuh secara alami karena penanaman yang dilakukan di daerah muara biasanya Rhizpohora. Hal ini dapat disebabkan karena mangrove jenis Avicennia tumbuh di daerah yang masih dipengaruhi oleh pasang surut. Kegiatan rehabilitasi di Desa Kaliwlingi dianggap lebih berhasil dibandingkan dengan Desa Sawojajar karena peran dan kepedulian stakeholder non pemerintahan dalam kegiatan tersebut.

Luas hutan mangrove di Desa Sawojajar dalam kurun waktu lima tahun juga mengalami penambahan. Tahun 2008 luas areal mangrove sebesar 24,39 ha bertambah 0,09 ha sehingga menjadi 24,48 ha di tahun 2013. Luas areal bertambah lagi sebesar 12,24 ha menjadi 36,72 ha di tahun 2018. Hal ini sesuai dengan persentase keberhasilan kegiatan rehabilitasi yang berkisar 7590\%. Berdasarkan Tabel 2, tahun 2008-2013 luas real kategori jarang berkurang 1,98 ha, kategori sedang bertambah 6,12 ha dan kategori rapat berkurang 4,05 ha. Sedangkan pada tahun 20132018 luas areal kategori jarang bertambah 9,18 ha, kategori sedang berkurang 0,72 ha dan kategori rapat bertambah 3,78 ha. Dari hasil interpretasi di lapangan, bertambahnya luas untuk kategori jarang dan berkurang untuk kategori sedang dikarenakan ukuran pohon mangrove yang

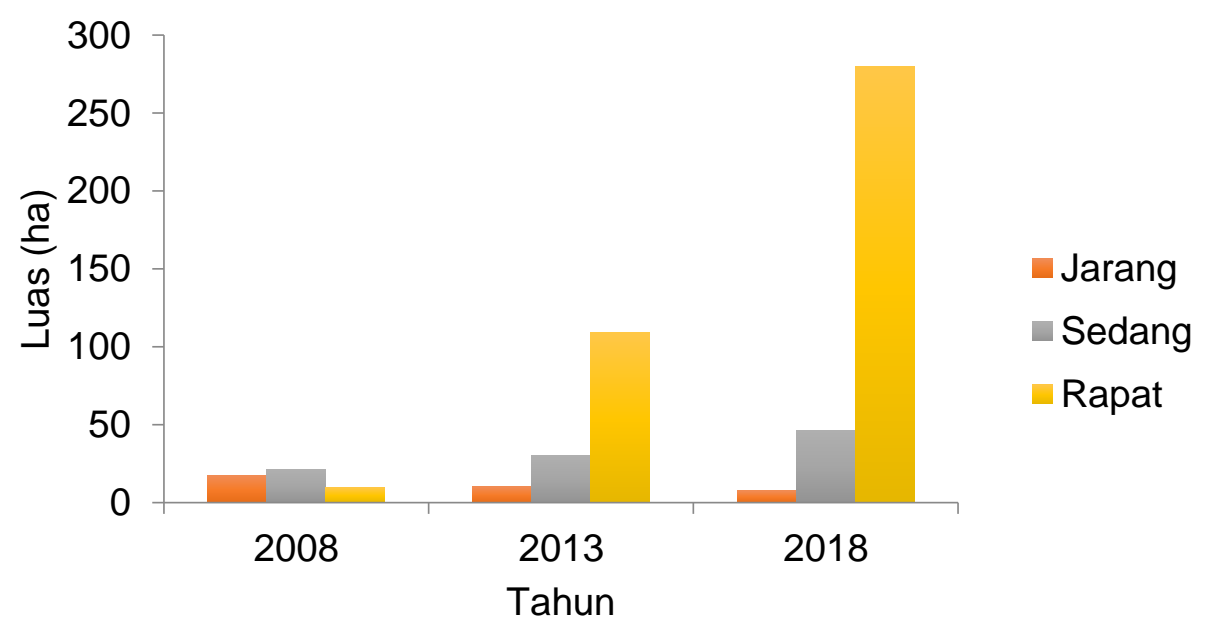

Gambar 1. Distribusi luas mangrove berdasarkan kategori kerapatannya di Desa Kaliwlingi tahun 2008, 2013 dan 2018 
Journal of Marine Research Vol.8, No.1 Februari 2019, pp. 27-35

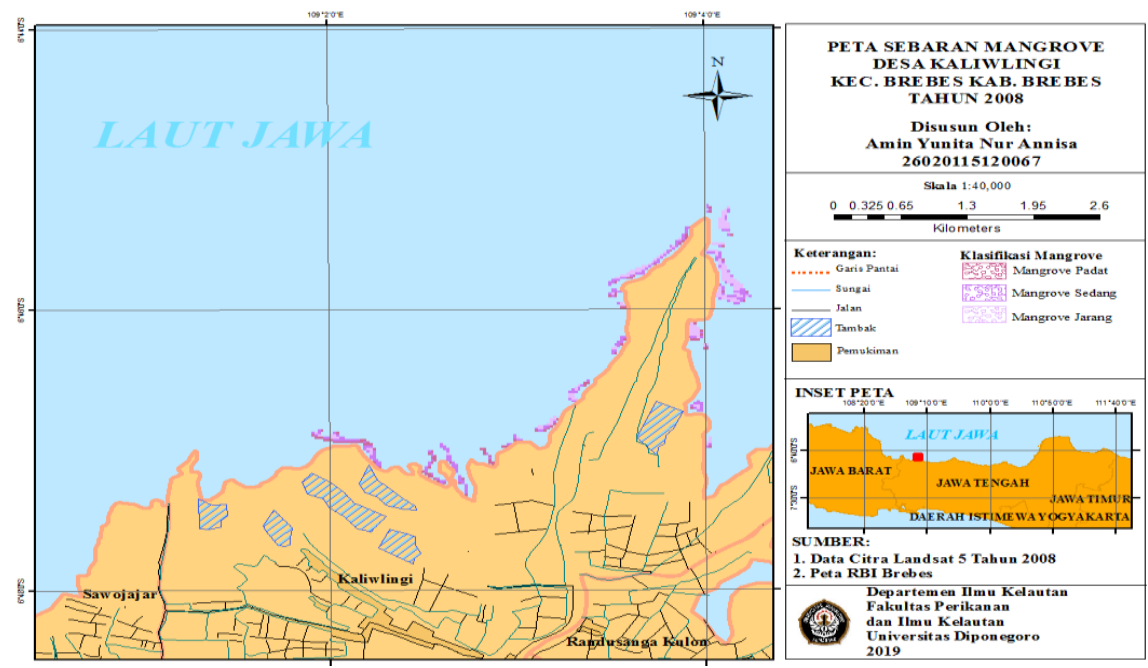

Gambar 3. Sebaran Mangrove Desa Kaliwlingi, Kecamatan Brebes Tahun 2008
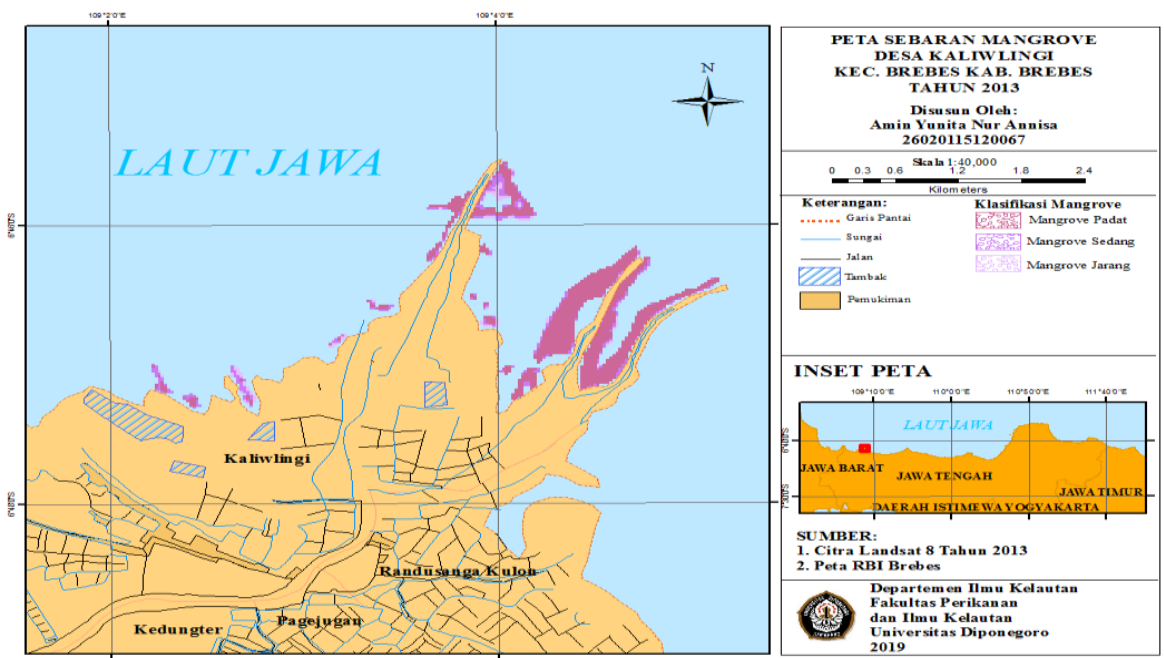

Gambar 4. Sebaran Mangrove Desa Kaliwlingi, Kecamatan Brebes Tahun 2013
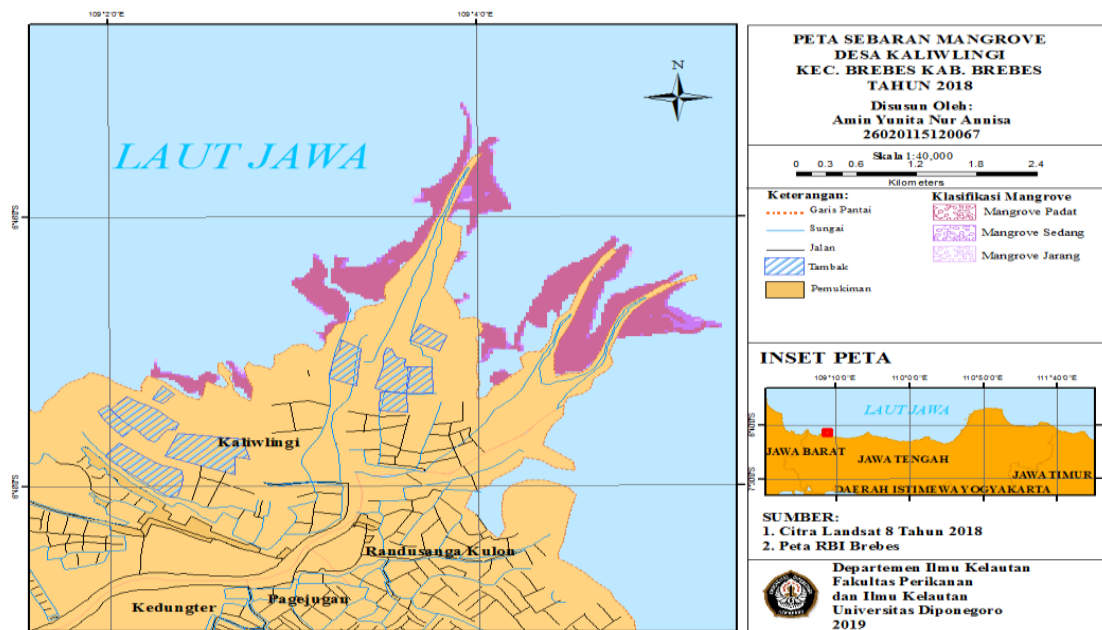

Gambar 5. Sebaran Mangrove Desa Kaliwlingi, Kecamatan Brebes Tahun 2018 
Journal of Marine Research Vol.8, No.1 Februari 2019, pp. 27-35

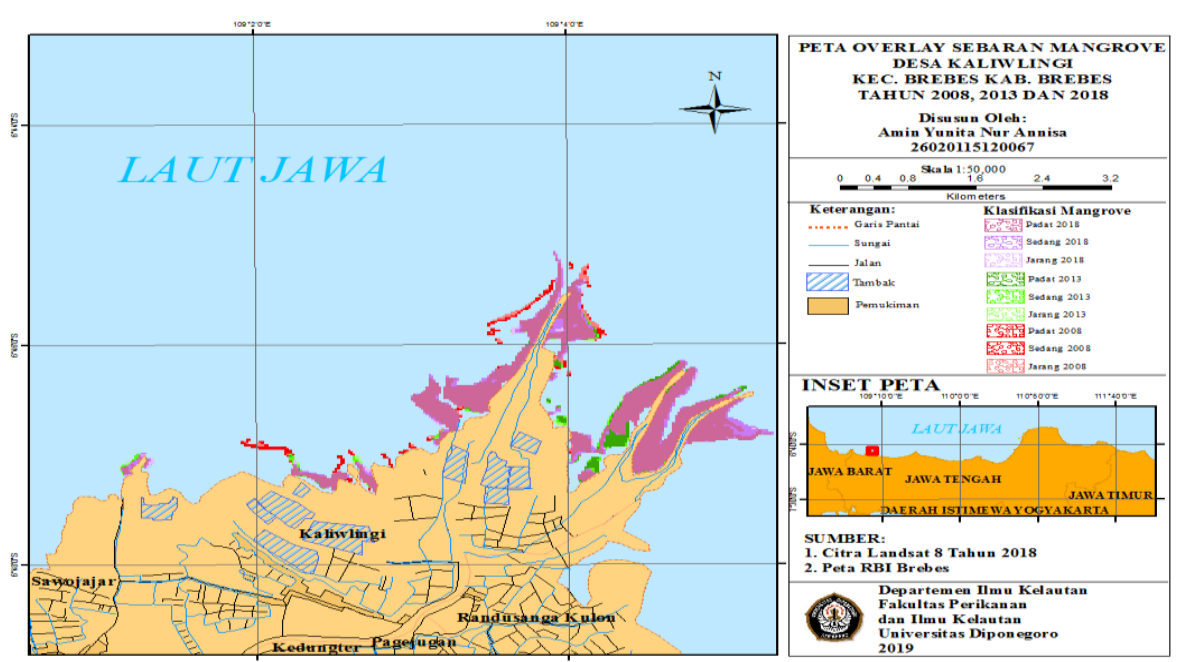

Gambar 6. Overlay Sebaran Mangrove Desa Kaliwlingi, Kecamatan Brebes Tahun 2008, 2013 dan 2018
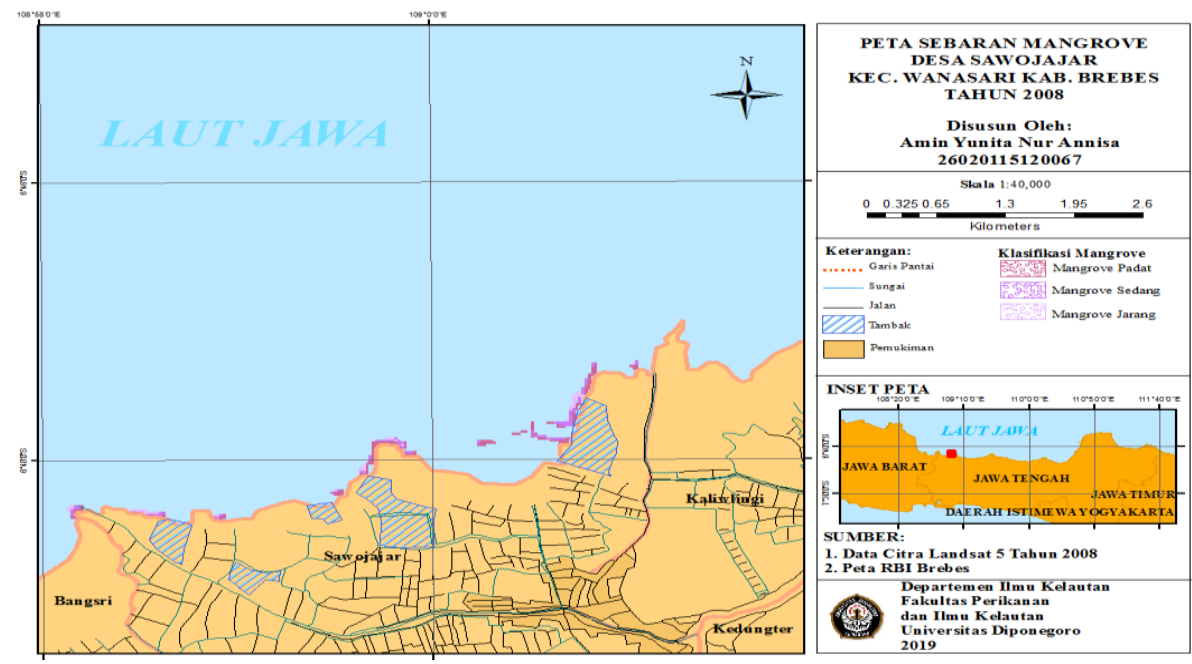

Gambar 7. Sebaran Mangrove Desa Sawojajar, Kecamatan Wanasari Tahun 2008
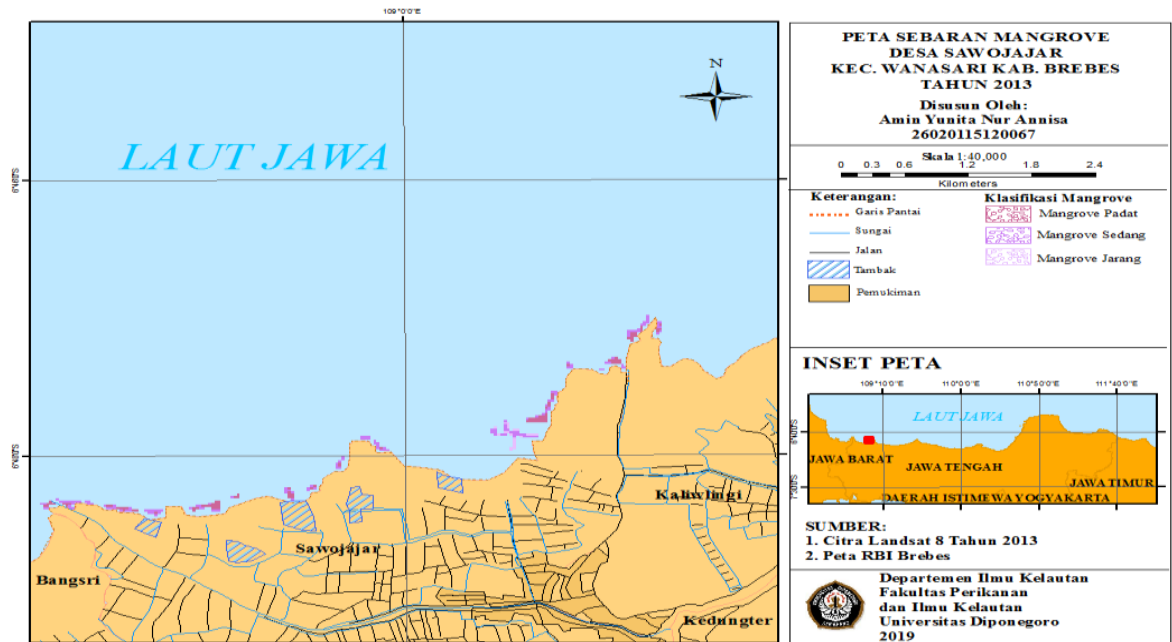

Gambar 8. Sebaran Mangrove Desa Sawojajar, Kecamatan Wanasari Tahun 2013 
Journal of Marine Research Vol.8, No.1 Februari 2019, pp. 27-35
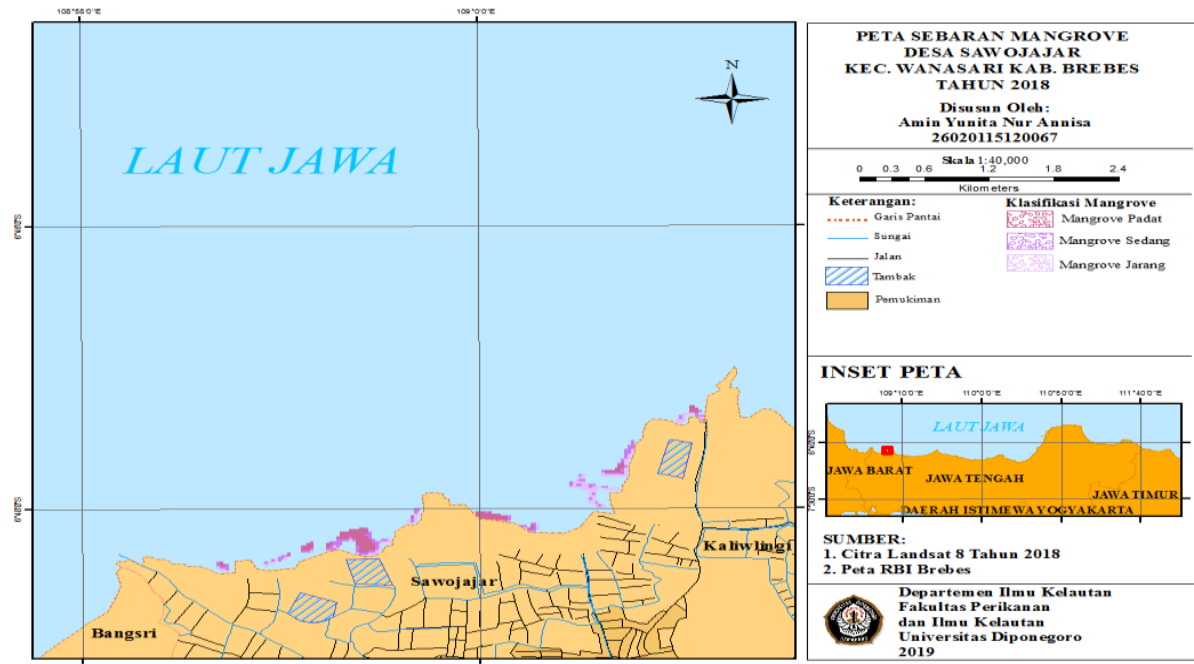

Gambar 9. Sebaran Mangrove Desa Sawojajar, Kecamatan Wanasari Tahun 2018
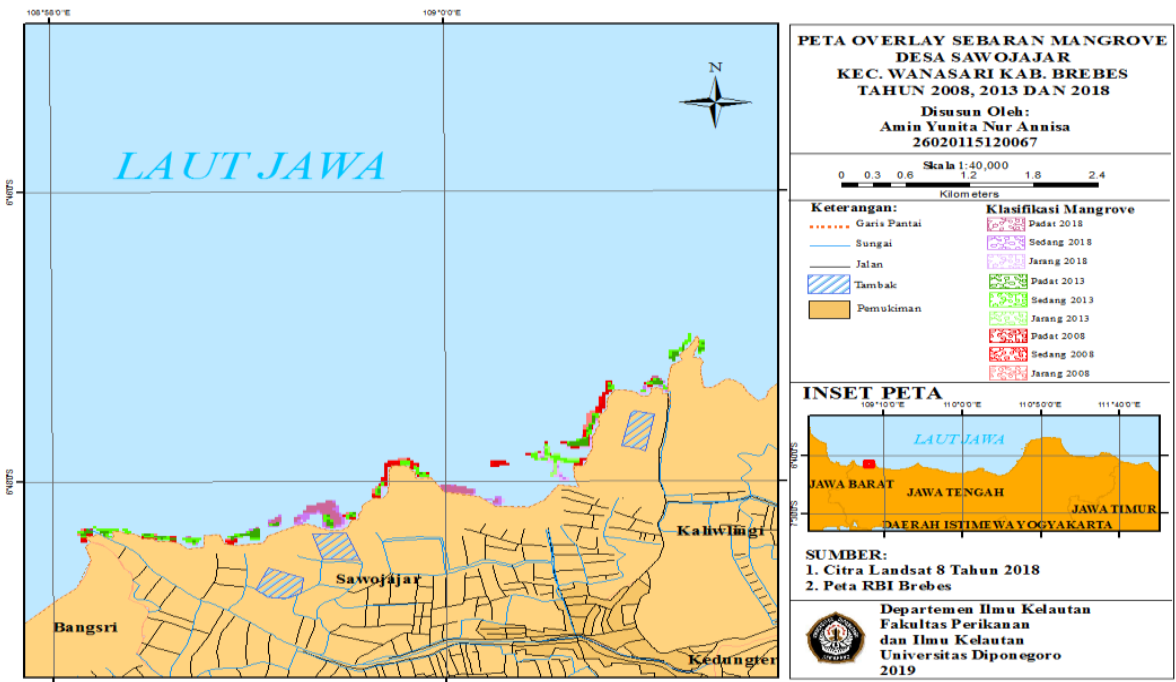

Gambar 10. Overlay Sebaran Mangrove Desa Sawojajar, Kecamatan Wanasari Tahun 2008, 2013 dan 2018

Tabel 2. Luas Perubahan Mangrove berdasarkan Tingkat Kerapatan

\begin{tabular}{|c|c|c|c|c|c|c|c|c|c|c|c|}
\hline \multirow{2}{*}{ Stasiun } & \multirow{2}{*}{ Kategori } & \multicolumn{2}{|c|}{2008} & \multicolumn{2}{|c|}{2013} & \multicolumn{2}{|c|}{2018} & \multicolumn{2}{|c|}{ Perubahan (ha) 2008-2013 } & \multicolumn{2}{|c|}{ Perubahan (ha) 2013-2018 } \\
\hline & & Pixel & ha & Pixel & ha & Pixel & ha & Pixel & ha & Pixel & ha \\
\hline \multirow{3}{*}{ Kaliwlingi } & Jarang & 194 & 17.46 & 114 & 10.26 & 87 & 7.83 & -80 & -7.2 & -27 & -2.43 \\
\hline & Sedang & 235 & 21.15 & 338 & 30.42 & 517 & 46.53 & +103 & +9.27 & +179 & +16.11 \\
\hline & Rapat & 109 & 9.81 & 1211 & 108.99 & 3106 & 279.54 & +1102 & +99.18 & +1895 & +170.55 \\
\hline \multicolumn{2}{|c|}{ TOTAL } & 538 & 48.42 & 1663 & 149.67 & 3710 & 333.9 & +1125 & +101.25 & +2047 & +184.23 \\
\hline \multirow{3}{*}{ Sawojajar } & Jarang & 45 & 4.05 & 23 & 2.07 & 125 & 11.25 & -22 & -1.98 & +102 & +9.18 \\
\hline & Sedang & 84 & 7.56 & 152 & 13.68 & 97 & 12.96 & +68 & +6.12 & -55 & -0.72 \\
\hline & Rapat & 142 & 12.78 & 97 & 8.73 & 139 & 12.51 & -45 & -4.05 & +42 & +3.78 \\
\hline \multicolumn{2}{|c|}{ TOTAL } & 271 & 24.39 & 272 & 24.48 & 361 & 36.72 & +1 & +0.09 & +89 & +12.24 \\
\hline
\end{tabular}


Tabel 3. Uji Validasi Hasil Interpretasi Citra Landsat 8 Tahun 2018 dengan Groundcheck Tahun 2018

\begin{tabular}{cccccccc}
\hline & \multicolumn{7}{c}{ Data Acuan (Lapangan) } \\
\hline & Mangrove & Tambak & Bangunan & Perairan & TOTAL & $\begin{array}{c}\text { USER ACCURACY } \\
(\%)\end{array}$ \\
\hline \multirow{2}{*}{ Data Hasil } & Mangrove & 6 & 0 & 0 & 0 & 6 & 100 \\
& Tambak & 0 & 6 & 0 & 2 & 8 & 75 \\
Klasifikasi & Bangunan & 0 & 0 & 8 & 0 & 8 & 100 \\
Total & Perairan & 0 & 0 & 0 & 4 & 4 & 100 \\
Producer & 6 & 6 & 8 & 6 & 26 & \\
Accuracy & 100 & 100 & 100 & 67 & & \\
\hline
\end{tabular}

Validasi seluruh hasil interpretasi $=\frac{(6+6+8+4)}{26} \times 100 \%=92 \%$

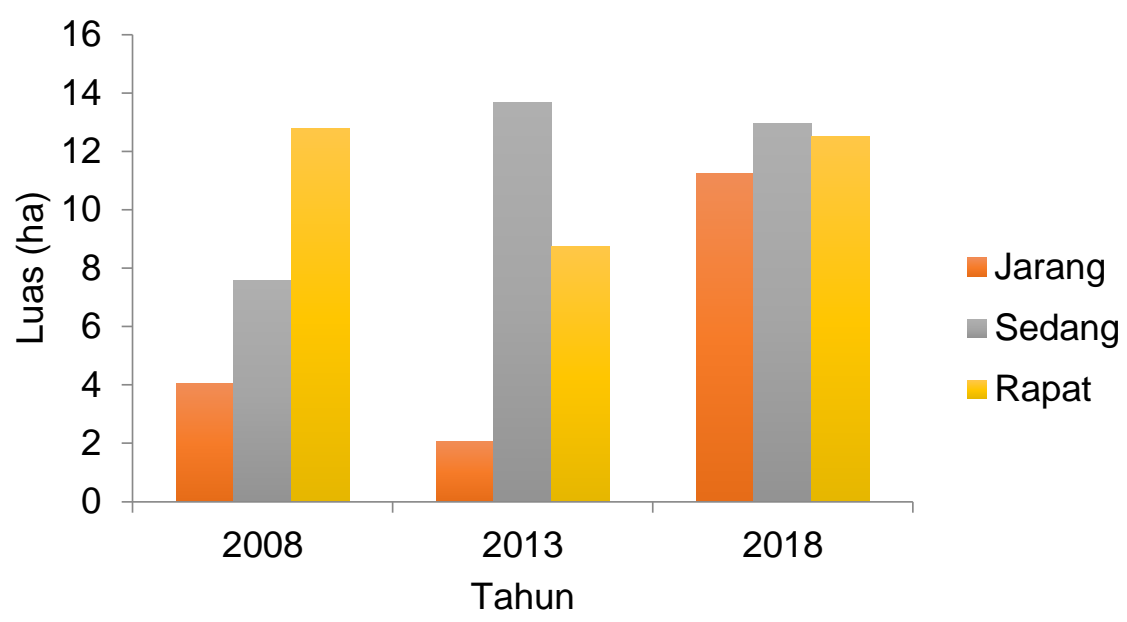

Gambar 2. Distribusi luas mangrove berdasarkan kategori kerapatannya di Desa Sawojajar tahun 2008, 2013 dan 2018

setiap tahun semakin bertambah ketinggiannya. Semakin tinggi pohon mangrove maka diameter batang pohon dan akar akan semakin lebar sedangkan untuk tutupan kanopi semakin rapat. Hal ini yang membuat kerapatan kategori sedang berkurang dan kategori jarang bertambah. Secara umum, keberhasilan kegiatan rehabilitasi dapat disebabkan oleh parameter fisik yang sesuai dengan jenis mangrove yang akan ditanam. Di dua desa $\mathrm{pH}$ rata- rata berkisar 8 . $\mathrm{pH} 8$ maka dapat dikatakan perairan tersebut memiliki tingkat kesuburan yangproduktif bahkan sangat produktif. Hal ini dikarenakan kisaran $\mathrm{pH}$ antara 6,5 - 7,5 dan 7,5-8,5. Suhu lingkungan di sekitar mangrove berkisar $25-30^{\circ} \mathrm{C}$. Berdasarkan Dinas Kehutanan (2006), mangrove dapat tumbuh optimal pada kisaran suhu $18-28^{\circ} \mathrm{C}$. Sehingga dapat dikatakan mangrove di Desa kaliwlingi dan Sawojajar tumbuh secara optimal.

\section{Uji Validasi}

Berdasarkan Tabel 3 diperoleh hasil uji validasi pemetaan sebaran mangrove sebesar $92 \%$. $\mathrm{Hal}$ ini menunjukkan bahwa informasi spasial sebaran mangrove yang dihasilkan memiliki tingkat akurasi yang memadai dan dapat dipercaya tingkat kebenarannya. Hasil uji validasi yang tidak mutlak $100 \%$ kemungkinan disebabkan perbedaan waktu antara perekaman citra dengan waktu groundcheck lapangan, sehingga kemungkinan terjadi perubahan kondisi lain. Uji ketelitian dengan nilai antara $85 \%-100 \%$ merupakan hasil penelitian yang layak uji, maka penelitian tersebut dapat dikategorikan sebagai penelitian yang layak uji (Sutanto, 1986).

Obyek yang dianalisa dibagi menjadi 2 obyek yaitu mangrove dan non mangrove (tambak, perairan dan bangunan). Jumlah titik sampling ada 26 titik, dimana 6 titik untuk mangrove dan 20 
titik untuk non mangrove. Untuk tingkat akurasi amgnrove, tambak, bangunan dan perairan yang telah dihitung melalui metode validasi diperoleh nilai akurasi mangrove sebesar $100 \%$, tambak $75 \%$, bangunan $100 \%$ dan perairan $100 \%$. Nilai comission error dari data tersebut yang paling besar adalah tambak sebesar $25 \%$, nilai producer accuracy yang paling sedikit adalah perairan $67 \%$, nilai omission error yang paling banyak adalah perairan 33\%. Omission error merupakan kesalahan klasifikasi berupa kekurangan jumlah piksel suatu kelas akibat masuknya piksel- piksel pada kelas tersebut ke kelas yang lain. Comission error merupakan kesalahan klasifikasi karena kelebihan jumlah piksel pada suatu kelas yang diakibatkan masuknya piksel dari kelas lain. Sedangkan producer accuracy merupakan peluang rata- rata (\%) suatu piksel menunjukkan sebaran masing- masing kelas di lapangan (Kusumaningrat et al., 2017). Pada tambak nilai uji validasi tidak mencapai $100 \%$, hal ini dimungkinkan ada saat perekaman semua jenis penggunaan lahan dalam kondisi pasang sehingga tambak yang berbatasan dengan perairan tertutup air pasang.

\section{KESIMPULAN}

Berdasarkan hasil klasifikasi citra Landsat tahun 2008,2013 dan 2018 luas mangrove di Desa Kaliwlingi dan Sawojajar bertambah dalam kurun waktu sepuluh tahun. Luas mangrove di Desa Kaliwlingi Kecamatan Brebes pada tahun 2008-2013 bertambah sebesar 101,25 ha yakni 48,42 ha pada tahun 2008 dan 149,67 ha pada tahun 2013. Pada tahun 2013-2018 juga bertambah 184,23 ha yakni 333,9 ha pada tahun 2018. Pada Desa Sawojajar Kecamatan Wanasari, luas mangrove juga bertambah sebesar 0,09 ha yakni 24,39 ha pada tahun 2008 bertambah menjadi 24,48 ha pada tahun 2013. Tahun 2013-2018 juga bertambah sebesar 12,24 ha sehingga menjadi 36,72 ha di tahun 2018.

\section{DAFTAR PUSTAKA}

Aryastana, P., Ardantha, I., Agustini, A. \& Komang, N., 2017. Analisis perubahan garis pantai dan laju erosi di Kota Denpasar dan Kabupaten Badung dengan citra satelit SPOT. Jurnal Fondasi, 6(2):100-111.

Dahuri, R., Rais, J., Ginting, S.P. \& Sitepu, D.M., 2001. Pengelolaan sumberdaya wilayah pesisir dan lautan secara terpadu. PT. Pradnya Paramita. Jakarta, 328.

Dinas Kehutanan. 2006. Inventarisasi dan Identifikasi Mangrove Wilayah Balai Pengelolaan DAS Pemali Jratun Provinsi Jawa Tengah. Direktorat Jenderal Rehabilitasi Lahan dan Perhutanan. Semarang.

Kusumaningrat, M.D., Subiyanto, S. \& Yuwono, B.D., 2017. Analisis Perubahan Penggunaan dan Pemanfaatan Lahan terhadap Rencana Tata Ruang Wilayah Tahun 2009 dan 2017 (Studi Kasus: Kabupaten Boyolali). Jurnal Geodesi Undip, 6(4):443-452.

Poedjirahajoe, E., 2011. Kajian Ekosistem Mangrove Hasil Rehabilitasi pada Berbagai Tahun tanam untuk Estimasi kandungan Tanin di Pantai Utara Jawa Tengah. Jurnal IImu Kehutanan, 5(2):99-107.

Purnamawati, P., Dewantoro, E., Sadri, S. \& Vatria, B., 2007. Manfaat Hutan Mangrove Pada Ekosistem Pesisir (Studi Kasus Di Kalimantan Barat). Media Akuakultur, 2(1):156-160.

Putra, A., Tanto, T.A., Farhan, A.R., Husrin, S. \& Pranowo, W.S. 2017. Pendekatan Metode Normalized Difference Vegetation Index (NDVI) Dan Lyzenga untuk Pemetaan Sebaran Ekosistem Perairan di Kawasan Pesisir Teluk Benoa-Bali. Geomatika, 23(2):87-94.

Sutanto, 1996. Penginderaan Jauh Jilid 1. Universitas Gajah Mada. Yogyakarta. 